\title{
Drug resistance profiles and clonality of sporadic Shigella sonnei isolates in Ankara, Turkey
}

\author{
Birgul Kacmaz ${ }^{1}$, Ozlem Unaldi ${ }^{2}$, Nedim Sultan ${ }^{3}$, Riza Durmaz ${ }^{2,4}$ \\ 1Central Microbiology Laboratory, Medical Faculty, Gazi University, Ankara, Turkey. \\ ${ }^{2}$ Molecular Microbiology Research and Application Laboratory, National Public Health Agency, \\ Ankara, Turkey. \\ ${ }^{3}$ Department of Clinical Microbiology, Medical Faculty, Gazi University, Ankara, Turkey. \\ ${ }^{4}$ Department of Clinical Microbiology, Medical Faculty, Kirikkale University, Kirikkale, Turkey.
}

Submitted: March 21, 2013; Approved: March 14, 2014.

\begin{abstract}
The aims of this study were to investigate drug resistance rates, types of extended spectrum beta lactamases (ESBLs), and molecular epidemiological characteristics of 43 Shigella sonnei isolates. Ampicillin-sulbactam, amoxicillin-clavulanate, chloramphenicol, and ciprofloxacin were the most active antibiotics. Five isolates harbored $b l a_{\mathrm{SHV}-12}, b l a_{\mathrm{TEM}-1}$ and $b l a_{\mathrm{CTX}-\mathrm{M}-15}$. More than $90 \%$ of the isolates had an indistinguishable pulsotype.
\end{abstract}

Key words: Shigella sonnei, extended spectrum beta-lactamase, plasmid profile, pulsed-field gel electrophoresis.

Shigellosis is a global human health problem caused by a group of bacteria called Shigella. There are four species of Shigella named S. sonnei, S. flexneri, S. dysenteriae, and $S$. boydii all of them capable of causing disease. In Turkey, S. sonnei is the most frequently reported Shigella species $(56.5 \%)$, followed by $S$. dysenteriae $(22.9 \%), S$. flexneri (14.5\%) and $S$. boydii (6.1\%) (http://www.saglik.gov.tr/istatistikler/temel2005/tablo-65. $\mathrm{htm}$.). Similarly, S. sonnei is the predominant serogroup in Ankara, the capital city of Turkey (Saran et al., 2013).

The increasing prevalence of antibiotic-resistant strains of Shigella has become a major concern worldwide. World Health Organization (WHO) recommends that all patients with bloody diarrhea should be treated with either ciprofloxacin or one of the following three drugs: pivmecillinam, azithromycin, and ceftriaxone (http://whqlibdoc.who.int/publica-

tions/2005/9241592330.pdf). However, there are many reports indicating fluoroquinolone resistant and extended spectrum beta-lactamase (ESBL)-producing Shigella isolates from certain countries in 2009-2011 years. (Nandy et al., 2010; Sabra et al., 2009; Varghese and Aggarwal, 2011).
Molecular typing and antimicrobial susceptibility of S. sonnei isolates can provide very useful data for the management of both isolated cases and outbreaks (DeLappe et al., 2003; Liang et al., 2007; Na-Ubol et al., 2006). In this study, we investigated the rate of antimicrobial resistance of $S$. sonnei strains collected in Ankara, the capital city of Turkey, from 2004 to 2006 and analyzed ESBL-producing isolates by PCR and DNA sequencing. Clonal relationship among the $S$. sonnei isolates was assessed using pulsed field gel electrophoresis (PFGE) and plasmid profile analysis.

A total of $43 \mathrm{~S}$. sonnei isolates were cultured from stool samples of patients with acute diarrhea. Isolates were collected at the Clinical Microbiology Laboratory of Gazi University Medical School Hospital in Ankara, Turkey during the three-year period between 2004 and 2006. Only one isolate was obtained from each patient. Twenty-three of the 43 patients $(53.5 \%)$ were male. The ages of the patients ranged from 5 to 75 years, with a mean of 14.1. The isolates were identified to species levels using conventional biochemical tests and group-specific polyvalent antisera, followed by phase specific antisera (Denka Seiken UK Ltd., Derbyshire, UK). Susceptibilities of the isolates to

Send correspondence to B. Kacmaz. Central Microbiology Laboratory, Medical Faculty, Gazi University, Ankara, Turkey. E-mail: kacmazbirgul@mynet.com. 
ampicillin, chloramphenicol, ciprofloxacin, ampicillin-sulbactam, amoxicillin-clavulanate, ceftriaxone, cefixime, and trimethoprim-sulfamethoxazole were determined by disk diffusion method according to the criteria recommended by the Clinical Laboratory Standards Institute (CLSI) (CLSI, 2010). ESBL production was determined by the double disk synergy method (Jarlier et al., 1988).

ESBL-producing $S$. sonnei isolates were tested for the presence of $\beta$-lactamase-encoding genes $b l a_{\mathrm{TEM}}, b l a_{\mathrm{SHV}}$ and $b l a_{\mathrm{CTX}-\mathrm{M}}$ by PCR. Approximately ten fresh colonies were suspended in sterile water, boiled for $10 \mathrm{~min}$, and centrifuged for $2 \mathrm{~min}$ at $13000 \mathrm{xg}$. The supernatant was used as DNA source. Universal primers described previously for the $\beta$-lactamase-encoding genes were used (Ma et al., 2005; Sidjabat et al., 2009). The reaction mixture contained either $2.5 \mathrm{mM} \mathrm{MgCl}_{2}$ for bla $_{\mathrm{SHV}} \mathrm{PCR}$ or $1.5 \mathrm{mM} \mathrm{MgCl}_{2}$ for $b l a_{\text {TEM }}$ and $b l a_{\text {CTX-M PCR, each of the deoxynucleoside }}$ triphosphates at a concentration of $200 \mu \mathrm{M}, 5 \mu \mathrm{L}$ of 10 PCR buffer [750 mM Tris- $\mathrm{HCl}(\mathrm{pH} 8.8), 200 \mathrm{mM}\left(\mathrm{NH}_{4}\right)_{2} \mathrm{SO}_{4}$, $0.1 \%(\mathrm{v} / \mathrm{v})$ Tween 20$], 10 \mathrm{pmol}$ of each primer, and $2.5 \mathrm{U}$ of Taq DNA polymerase (Thermo Scientific-Fermentas Corporation, Vilnius, Lithuania) in a final reaction volume of $50 \mu \mathrm{L}$. Amplification of $b l a_{\mathrm{TEM}}$ and $b l a_{\mathrm{CTX} \text {-M }}$ was performed using the following conditions: initial denaturation at $94{ }^{\circ} \mathrm{C}$ for $4 \mathrm{~min}$, followed by 40 cycles of $94{ }^{\circ} \mathrm{C}$ for $15 \mathrm{~s}$, $55^{\circ} \mathrm{C}$ for $45 \mathrm{~s}$, and $72{ }^{\circ} \mathrm{C}$ for $1 \mathrm{~min}$, with a final extension step at $72{ }^{\circ} \mathrm{C}$ for $7 \mathrm{~min}$. Amplification conditions for $b l a_{\mathrm{SHV}}$ were as follows: initial denaturation at $94{ }^{\circ} \mathrm{C}$ for $5 \mathrm{~min}$, followed by 25 cycles of $94{ }^{\circ} \mathrm{C}$ for $30 \mathrm{~s}, 55^{\circ} \mathrm{C}$ for $30 \mathrm{~s}$, and $72{ }^{\circ} \mathrm{C}$ for $30 \mathrm{~s}$, with a final extension step at $72{ }^{\circ} \mathrm{C}$ for $7 \mathrm{~min}$. The amplified DNA products were analyzed by $1.5 \%$ agarose gel electrophoresis in 1x TBE buffer and stained with ethidium bromide.

PCR products of $b l a_{\mathrm{TEM}}, b l a_{\mathrm{SHV}}$, and bla $_{\mathrm{CTX}-\mathrm{M}}$ genes were purified using Agencourt Ampure (Beckman Coulter Company, Massachusetts, USA). Sequencing reactions were performed with the primers used for PCR reactions. Each sequence reaction mixture consisted of 3.5-5 $\mu \mathrm{L}$ purified amplicon, 5 pmol primer, and $4 \mu \mathrm{L}$ of Dye terminator cycle sequencing quick start kit (Beckman Coulter Company, Massachusetts, USA). The sequence reaction was done as follows: initial denaturation at $94{ }^{\circ} \mathrm{C}$ for $3 \mathrm{~min}$ followed by 30 cycles consisting of denaturation at $96^{\circ} \mathrm{C}$ for $20 \mathrm{~s}$, annealing at $55^{\circ} \mathrm{C}$ for $20 \mathrm{~s}$, and elongation at $60{ }^{\circ} \mathrm{C}$ for $4 \mathrm{~min}$. The PCR products were purified with Dye-Terminator removal kit (Beckman Coulter Company, Massachusetts, USA) and $20 \mu \mathrm{L}$ of purified product was sequenced in Beckman Coulter 8000 instrument. The resulting DNA sequences were compared with the GenBank sequence databases using BLAST (http://blast.ncbi.nlm.nih.gov/Blast.cgi).

Plasmid profiles analysis of the $S$. sonnei isolates was carried on plasmids obtained by using the alkaline-lysis method described by Kado and Liu (1981) with some modi- fications. Our modifications included culturing the isolates in ampicillin containing medium and exclusion of the phenol/chloroform prufication step. Molecular sizes of plasmids were determined by using super coiled DNA ladder (Life Technologies, Carlsbad, CA, USA).

PFGE typing of the $43 \mathrm{~S}$. sonnei isolates was performed by following the protocol of Durmaz et al. (2009). Briefly, bacterial cells were embedded into low melting agarose including sodium dodecyl sulfate. Cells in plugs were digested with lysozyme and proteinase K. Genomic DNA was restricted by $20 \mathrm{U}$ of $\mathrm{XbaI}$ (Thermo Scientific-Fermentas Corporation, Vilnius, Lithuania). DNA fragments were separated by using a CHEF-DR II system (Bio-Rad Laboratories, Nazareth, Belgium). The DNA band profiles were analyzed with GelCompar software (version 3.0; Applied Maths, Sint-Martens-Latem, Belgium). A $1 \%$ band tolerance was used for comparison of DNA profiles. Clonal relationship among isolates was evaluated by using the criteria of Tenover et al. (1997).

All 43 isolates were confirmed as S. sonnei using group-specific polyvalent antisera and phase specific antisera. According to the serotyping results, 28 (65\%) of the 43 isolates showed phase 1, eight (19\%) showed phase 2, and seven (16\%) showed both phase 1 and 2 profiles $(+1)$. According to the antibiotic resistance profiles, four antibiotypes were designated as shown in Table 1. Since more than $83 \%$ of the isolates were classified in only one antibiotype (type 2), it was very difficult to discuss usefulness of the antibiotyping on our isolates collected during the three-year period. In this study, S. sonnei isolates showed the low rate of susceptibility against trimethoprim-sulfamethoxazole (5\%). In agreement with our results, previous studies from Turkey and other countries also indicated small susceptibility rates (3.5-30\%) (Akcali et al., 2008; Altun and Gur, 2011; Jafari et al., 2009; Saran et al., 2013; Zafar et al., 2009). The studies from Iran and Israel revealed $57 \%$ and $87 \%$ resistance to ampicillin, respectively (Ashkenazi et al., 2003; Jafari et al., 2009). In contrast to the results reported from those countries, low resistance rate was found in the current $(12 \%)$ and previous studies (17\% and 20\%) from our country (Akcali et al., 2008; Altun and Gur, 2011). In accordance with some studies (Akcali et al., 2008; Altun and Gur, 2011; DeLappe et al., 2003), we found that all $S$. sonnei isolates were susceptible to ampicillin-sulbactam, chloramphenicol, and ciprofloxacin. However, other works have reported different resistance rates $(9 \%$ to $100 \%)$ for chloramphenicol (Ashkenazi et al., 2003; Jafari et al., 2009).

In our study, resistance to ceftriaxone and cefixime was only detected in five (12\%) ESBL-producing isolates. ESBL-positive $S$. sonnei isolates were also reported in Lebanon (8\%) (Sabra et al., 2009), Kuwait (2.8\%) (Jamala et al., 2010), China, and India (Izumiya et al., 2009). One of the ESBL-positive isolates carried $b l a_{\mathrm{SHV}-12}$ and four harbored bla $_{\mathrm{CTX} \text {-M-15 }}$ genes. To the best of our knowledge, this 
Table 1 - Distribution of S. sonnei strains according to epidemiologic, phenotypic and molecular typing characteristics.

\begin{tabular}{|c|c|c|c|c|c|c|c|c|c|c|c|c|}
\hline \multirow{2}{*}{$\begin{array}{l}\text { Strain } \\
\text { No }\end{array}$} & \multirow{2}{*}{$\begin{array}{c}\text { Isolation } \\
\text { date }(\mathrm{m} / \mathrm{d} / \mathrm{y})\end{array}$} & \multicolumn{7}{|c|}{ Antibiotic susceptibility pattern } & \multicolumn{2}{|c|}{ Phase type } & \multirow{2}{*}{$\begin{array}{l}\text { PFGE } \\
\text { type }\end{array}$} & \multirow{2}{*}{$\begin{array}{l}\text { Plasmid } \\
\text { profile }\end{array}$} \\
\hline & & $\mathrm{AMC}$ & $\mathrm{CRO}$ & CTX & AMP & SXT & CFM & Antibiotypes & Phase 1 & Phase 2 & & \\
\hline 1 & 08.27 .2005 & S & $\mathrm{S}$ & S & S & $\mathrm{R}$ & S & 2 & - & + & $\mathrm{A}$ & I \\
\hline 2 & & S & $\mathrm{S}$ & S & S & $\mathrm{R}$ & S & 2 & + & + & A & I \\
\hline 3 & 09.30 .2005 & $\mathrm{~S}$ & $\mathrm{~S}$ & $\mathrm{~S}$ & S & $\mathrm{R}$ & $\mathrm{S}$ & 2 & + & - & A & I \\
\hline 4 & 09.08 .2004 & $\mathrm{~S}$ & $\mathrm{~S}$ & S & S & $\mathrm{R}$ & $\mathrm{S}$ & 2 & + & + & A & I \\
\hline 5 & & S & $\mathrm{S}$ & S & S & $\mathrm{R}$ & S & 2 & + & - & A & I \\
\hline 6 & 10.13 .2005 & $\mathrm{~S}$ & $\mathrm{~S}$ & $\mathrm{~S}$ & S & $\mathrm{R}$ & $\mathrm{S}$ & 2 & + & - & A & II \\
\hline 7 & 09.11 .2005 & $\mathrm{~S}$ & $\mathrm{~S}$ & S & S & $\mathrm{R}$ & $\mathrm{S}$ & 2 & + & - & A & I \\
\hline 8 & 09.26 .2005 & S & $\mathrm{S}$ & S & S & $\mathrm{R}$ & $\mathrm{S}$ & 2 & + & - & A & I \\
\hline 9 & & S & $\mathrm{S}$ & S & S & $\mathrm{R}$ & S & 2 & + & + & A & VI \\
\hline $10^{*}$ & & $\mathrm{~S}$ & $\mathrm{R}$ & $\mathrm{R}$ & $\mathrm{R}$ & $\mathrm{R}$ & $\mathrm{R}$ & 3 & - & + & A & I \\
\hline $11^{*}$ & 10.03 .2005 & S & $\mathrm{R}$ & $\mathrm{R}$ & $\mathrm{R}$ & $\mathrm{R}$ & $\mathrm{R}$ & 3 & + & + & A & I \\
\hline $12^{*}$ & 10.17 .2004 & $\mathrm{R}$ & $\mathrm{R}$ & $\mathrm{R}$ & $\mathrm{R}$ & $\mathrm{R}$ & $\mathrm{R}$ & 4 & + & - & A & I \\
\hline 13 & 08.29 .2005 & $\mathrm{~S}$ & $\mathrm{~S}$ & S & S & $\mathrm{R}$ & $\mathrm{S}$ & 2 & + & - & A & II \\
\hline 14 & 09.26 .2005 & S & $\mathrm{S}$ & S & S & $\mathrm{R}$ & $\mathrm{S}$ & 2 & + & + & A & VII \\
\hline 15 & 05.29 .2005 & S & $\mathrm{S}$ & S & S & $\mathrm{R}$ & S & 2 & + & - & A & I \\
\hline 16 & 08.27 .2005 & S & S & S & S & $\mathrm{R}$ & $\mathrm{S}$ & 2 & + & - & A & I \\
\hline 17 & 09.30 .2005 & S & $\mathrm{S}$ & S & S & $\mathrm{R}$ & $\mathrm{S}$ & 2 & + & - & A & I \\
\hline 18 & & S & S & S & S & $\mathrm{R}$ & S & 2 & + & - & A & I \\
\hline 19 & 08.26 .2005 & S & S & S & S & $\mathrm{R}$ & $\mathrm{S}$ & 2 & + & - & A & II \\
\hline 20 & 09.28 .2006 & $\mathrm{~S}$ & $\mathrm{~S}$ & S & S & $\mathrm{R}$ & $\mathrm{S}$ & 2 & + & + & A & I \\
\hline 21 & 09.29 .2006 & S & $\mathrm{S}$ & $\mathrm{S}$ & S & $\mathrm{R}$ & S & 2 & + & - & A & V \\
\hline 22 & 09.26 .2006 & S & S & S & S & $\mathrm{R}$ & $\mathrm{S}$ & 1 & + & - & A & I \\
\hline 23 & & $\mathrm{~S}$ & $\mathrm{~S}$ & S & S & $\mathrm{R}$ & $\mathrm{S}$ & 2 & + & - & A & IX \\
\hline $24^{*}$ & & $\mathrm{~S}$ & $\mathrm{R}$ & $\mathrm{R}$ & $\mathrm{R}$ & $\mathrm{R}$ & $\mathrm{R}$ & 3 & + & - & $\mathrm{A} 1$ & II \\
\hline 25 & & $\mathrm{~S}$ & $\mathrm{~S}$ & S & S & $\mathrm{R}$ & $\mathrm{S}$ & 2 & + & - & B & III \\
\hline 26 & 01.10 .2005 & $\mathrm{~S}$ & $\mathrm{~S}$ & $\mathrm{~S}$ & S & $\mathrm{R}$ & $\mathrm{S}$ & 2 & + & - & B & I \\
\hline 27 & & S & $\mathrm{S}$ & S & S & $\mathrm{R}$ & S & 2 & + & - & B & III \\
\hline 28 & 10.16 .2005 & $\mathrm{~S}$ & $\mathrm{~S}$ & $\mathrm{~S}$ & S & $\mathrm{R}$ & $\mathrm{S}$ & 2 & - & + & $\mathrm{C}$ & IV \\
\hline 29 & 09.28 .2005 & $\mathrm{~S}$ & $\mathrm{~S}$ & S & S & $\mathrm{R}$ & $\mathrm{S}$ & 2 & - & + & $\mathrm{C}$ & $\mathrm{V}$ \\
\hline 30 & & $\mathrm{~S}$ & $\mathrm{~S}$ & S & S & $\mathrm{R}$ & S & 2 & - & + & $\mathrm{C}$ & I \\
\hline 31 & 08.26 .2005 & $\mathrm{~S}$ & $\mathrm{~S}$ & S & S & $\mathrm{R}$ & $\mathrm{S}$ & 2 & + & - & $\mathrm{C}$ & I \\
\hline 32 & 09.24 .2005 & $\mathrm{~S}$ & $\mathrm{~S}$ & $\mathrm{~S}$ & S & $\mathrm{R}$ & $\mathrm{S}$ & 2 & + & + & $\mathrm{C} 1$ & I \\
\hline 33 & 09.30 .2005 & $\mathrm{~S}$ & $\mathrm{~S}$ & S & S & $\mathrm{R}$ & $\mathrm{S}$ & 2 & + & - & $\mathrm{D}$ & I \\
\hline 34 & & $\mathrm{~S}$ & $\mathrm{~S}$ & $\mathrm{~S}$ & S & $\mathrm{R}$ & $\mathrm{S}$ & 2 & + & - & $\mathrm{D}$ & I \\
\hline $35^{*}$ & 09.12 .2005 & $\mathrm{~S}$ & $\mathrm{R}$ & $\mathrm{R}$ & $\mathrm{R}$ & $\mathrm{R}$ & $\mathrm{R}$ & 3 & + & - & $\mathrm{D}$ & I \\
\hline 36 & 09.20 .2005 & $\mathrm{~S}$ & $\mathrm{~S}$ & S & S & $\mathrm{R}$ & $\mathrm{S}$ & 2 & - & + & D1 & I \\
\hline 37 & & $\mathrm{~S}$ & $\mathrm{~S}$ & S & S & $\mathrm{R}$ & $\mathrm{S}$ & 2 & + & - & $\mathrm{E}$ & III \\
\hline 38 & 09.24 .2006 & $\mathrm{~S}$ & $\mathrm{~S}$ & S & S & $\mathrm{R}$ & $\mathrm{S}$ & 2 & + & - & $\mathrm{E}$ & III \\
\hline 39 & 10.19 .2005 & $\mathrm{~S}$ & $\mathrm{~S}$ & S & S & $\mathrm{R}$ & $\mathrm{S}$ & 2 & - & + & E1 & IV \\
\hline 40 & & S & $\mathrm{S}$ & S & S & $\mathrm{R}$ & $\mathrm{S}$ & 2 & + & - & $\mathrm{F}$ & II \\
\hline 41 & & S & $\mathrm{S}$ & $\mathrm{S}$ & S & $\mathrm{R}$ & S & 2 & + & - & $\mathrm{F}$ & III \\
\hline 42 & 09.18 .2006 & S & $\mathrm{S}$ & S & S & $\mathrm{R}$ & S & 2 & + & - & $\mathrm{F}$ & I \\
\hline 43 & & S & $\mathrm{S}$ & S & S & $\mathrm{S}$ & $\mathrm{S}$ & 1 & - & + & $\mathrm{F}$ & VIII \\
\hline
\end{tabular}

* ESBL-producing isolates: Isolate 10, 12 had $b l a_{\mathrm{CTX}-\mathrm{M}-15}$, isolate 11,35 had both $b l a_{\mathrm{CTX}-\mathrm{M}-15}$ and $b l a_{\mathrm{TEM}-1}$, isolate 24 had both $b l a_{\mathrm{TEM}-1}$ and $b l a_{\mathrm{SHV}-12}$ 
is the first report of the presence $b l a_{\mathrm{SHV}-12} \beta$-lactamase gene in a $S$. sonnei strain isolated in Turkey.

Nine different plasmid profiles (I-IX) were detected. The size of the plasmids ranged from 2 to $10 \mathrm{~kb}$. Two plasmids with approximately 3 - and 5 - $\mathrm{kb}$ in size were present in more than $90 \%$ of the isolates. Twenty-five of the 43 $S$. sonnei isolates were classified in plasmid profile I (Table 1). Plasmid profiles of four $b l a_{\text {СтХ-M-15-producing iso- }}$ lates were the same (profile I). Although it was indicated that plasmid profile analysis is one of the appropriate methods for molecular characterization of Shigella isolates recovered over short time periods (12), we could not find any epidemiological link among the isolates classified in the same plasmid profile. For instance, the predominant plasmid profile I included more than half of the isolates collected from 2004 to 2006.

PFGE typing of the $43 \mathrm{~S}$. sonnei isolates yielded 10 different profiles, six (A, B, C, D, E, and F) were indistinguishable profiles including 23, 3, 4, 3, 2, and 4 isolates, respectively and the remaining four $\left(\mathrm{A}_{1}, \mathrm{C}_{1}, \mathrm{D}_{1}\right.$, and $\left.\mathrm{E}_{1}\right)$ were closely related profiles having 1 to 2 band-differences from their related clones. Genetic heterogeneity among different PFGE profiles was very low. According to similarity percentage of $>82 \%$, two major PFGE profiles were determined, Group 1 included 39 isolates, and Group 2 included four isolates. There were 1-2 band-differences among PFGE profiles in major group I, while there were four differences between major group 1 and group 2 (Figure 1).

We observed limited correlation between the typing results and epidemiological characteristics. Plasmid profile I was found in five distinct PFGE types (PFGE types A, B, $\mathrm{C}, \mathrm{D}$, and F) and a common PFGE type (PFGE type A) were found in six different plasmid profiles (profile I, II, V, VI, VII, and IX). In parallel to our data, Pichel et al. (2007) found similar plasmid profiles in distinct PFGE clones and five different plasmid profiles in one outbreak clone. Four CTX-M-15-producing isolates showed three different PFGE types, two plasmid profiles, and two antibiotypes. PFGE type A was predominant both in phase 1 and phase $1+2$ serotypes. Twenty-three $(82 \%)$ of the 28 isolates classified in the phase 1 serotype, 5 (62\%) of the 8 isolates classified in the phase 2 , and $6(86 \%)$ of the 7 isolates classified in the phase $1+2$ showed the type 2 antibiotic resistance phenotype. There were no correlation between PFGE types and antibiogram types, however at least half of the isolates of each antibiotype showed PFGE profile A. Although the previous studies revealed that PFGE was the most discriminatory method among subtyping methods (DeLappe et al., 2003; Na-Ubol et al., 2006; Pichel et al., 2007), the $S$. sonnei isolates analyzed in the current study showed very low genetic diversity and there was no direct epidemiological relationship among the isolates having indistinguishable PFGE profiles. For instance, 23 isolates classified in PFGE profile "A" were isolated from the first week of September 2004 to the last week of September 2006. On the

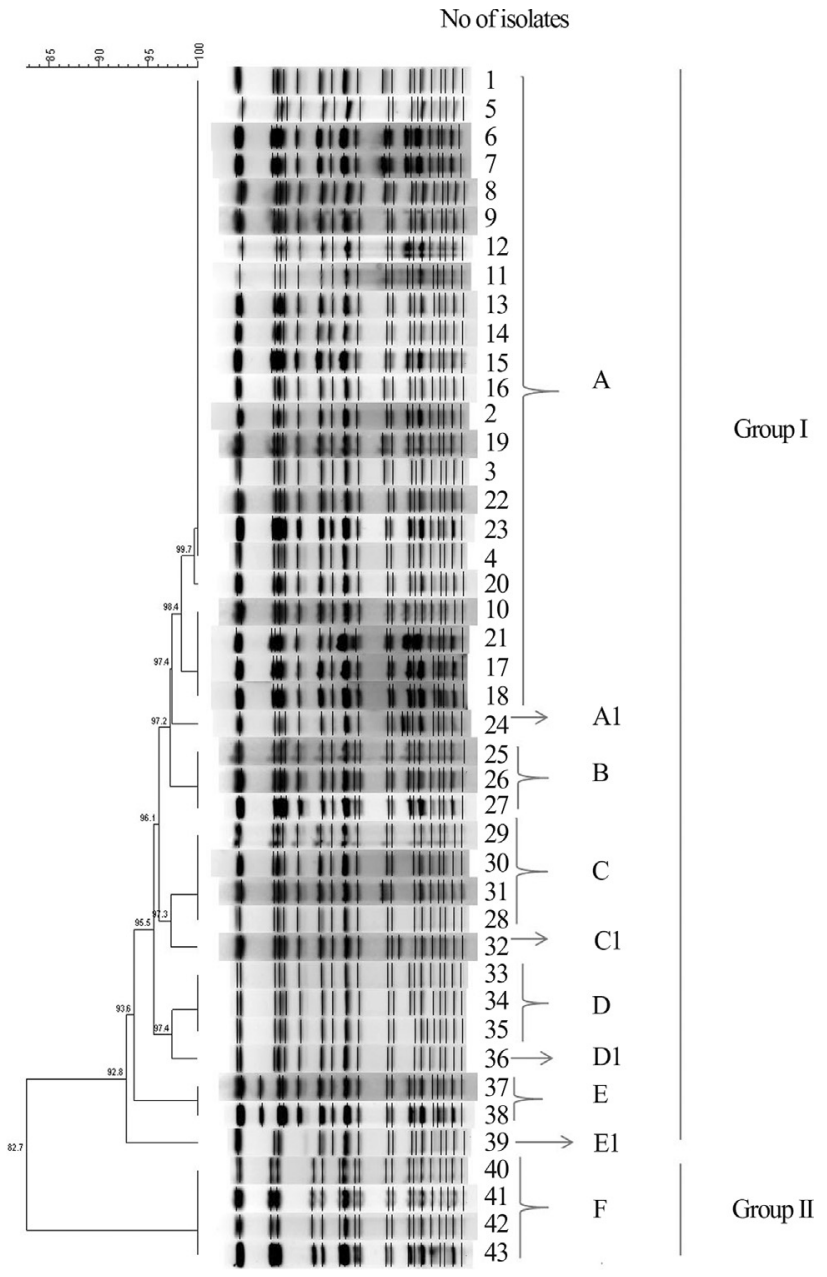

Figure 1 - Dendrogram of the PFGE patterns of the $43 \mathrm{~S}$. sonnei isolates. A, B, C, D, E, and F were indistinguishable profiles including 23, 3, 4, 3, 2 , and 4 isolates, respectively. A1, C1, D1, and E1 were closely related PFGE profiles having 1 to 2 band-differences from the related clones.

other hand, the strains isolated from patient 2 and patient 7 with an interval of three days showed different PFGE profiles " $E_{1}$ " and " $C$ ", respectively. In parallel to our results, a study carried on the Shigella isolates from Ankara has also indicated high relationship among the tested isolates (Saran et al., 2013). These findings support the comment that PFGE is a powerful tool for shigellosis outbreak investigation. However it has some disadvantages for the investigation of clonal relationships among $S$. sonnei strains circulating over a period of months or years (Liang et al., 2007).

In conclusion, this is the first report indicating the presence of bla $a_{\mathrm{SHV}-12}$ in $S$. sonnei in Turkey. High genetic homology among the sporadic S. sonnei isolates may indicate ongoing cross-transmission for a long period rather than a recent transmission. 


\section{References}

Akcali A, Levent B, Akbas E, Esen B (2008) Typing of Shigella sonnei strains isolated in some provinces of Turkey using antimicrobial resistance and pulsed field gel electrophoresis methods. Mikrobiyol Bul 42:563-572.

Altun B, Gur D (2011) Antimicrobial resistance profiles of Shigella spp. isolated from feces samples in Hacettepe University Ihsan Dogramaci Children's hospital between 1999-2010. Mikrobiyol Bul 45:609-616.

Ashkenazi S, Levy I, Kazaronovski V, Samra Z (2003) Growing antimicrobial resistance of Shigella isolates. J Antimicrobial Chemotherapy 51:427-429.

Clinical and Laboratory Standards Institue (2010) Performance standards for antimicrobial susceptibility testing; Twentieth informational supplement M100-S20 Vol.30 No.1.

DeLappe N, O’Halloran F, Fanning S, Corbett-Feeney G, Cheasty $\mathrm{T}$, Cormican M (2003) Antimicrobial resistance and genetic diversity of Shigella sonnei isolates from western Ireland, an area of low incidence of infection. J Clin Microbiol 41:1919-1924.

Durmaz R, Otlu B, Koksal F, Hosoglu S, Ozturk R, Ersoy Y, Aktas E, Gursoy NC, Caliskan A (2009) The optimization of a rapid pulsed-field gel electrophoresis protocol for the typing of Acinetobacter baumannii, Escherichia coli and Klebsiella spp. Jpn J Infect Dis 62:372-377.

Izumiya $\mathrm{H}$, Tada $\mathrm{Y}$, Ito $\mathrm{K}$, Morita-Ishihara $\mathrm{T}$, Ohnishi M, Terajima J, Watanabe H (2009) Characterization of Shigella sonnei isolates from travel-associated cases in Japan. J Med Microbiol 58:1486-1491.

Jafari F, Hamidian M, Rezadehbashi M, Doyle M, Salmanzadeh-ahrabi S, Derakhshan F, Zali MR (2009) Prevalence and antimicrobial resistance of diarrheagenic Escherichia coli and Shigella species associated with acute diarrhea in Tehran, Iran. Can J Infect Dis Med Microbiol 20:e56-e61.

Jamala W, Rotimia VO, Palb T, Sonnevendb A, Dimitrove TS (2010) Comparative in vitro activity of tigecycline and other antimicrobial agents against Shigella species from Kuwait and the United Arab of Emirates. J Infect Public Health 3:35-42.

Jarlier V, Nicolas M H, Fournier G, Philippon A (1988) Extended broad-spectrum beta-lactamases conferring transferable resistance to newer beta-lactam agents in Enterobacteriaceae: Hospital prevalence and susceptibility patterns. Rev Infect Dis 10:867-878.

Kado CL, Liu ST (1981) Rapid procedure for detection of large and small plasmids. J Bacteriol 145:1365-1373.

Liang SY, Watanabe H, Terajima J, Li CC, Liao JC, Tung SK, Chiou CS (2007) Multilocus variable-number tandemrepeat analysis for molecular typing of Shigella sonnei. J Clin Microbiol 45:3574-3580.

Ma L, Alba J, Chang F, Ishiguro M, Yamaguchi K, Siu LK, Ishii Y (2005) A novel SHV-derived extended-spectrum $\beta$-lacta- mase (SHV-57) that confers resistance to ceftazidime but not cefazolin. Antimicrob Agents Chemother 49:600-605.

Nandy S, Mitra U, Rajendran K, Dutta P, Dutta S (2010) Subtype prevalence, plasmid profiles and growing fluoroquinolone resistance in Shigella from Kolkata, India (2001-2007): A hospital-based study. Trop Med Int Health 15:1499-1507.

Na-Ubol M, Samosornsuk S, Seidlein Lv, Tapchaisri P, Ali M, Clemens JD, Chaicumpa W (2006) Molecular characteristics of Shigella spp. isolated from patients with diarrhoea in a new industrialized area of Thailand. Epidemiol Infect 134:997-1003.

Pichel M, Gonzalez Fraga S, Terragno R, Mulki J, Gentile A, Kremer C, Mola AM, Noseda R, Binsztein N (2007) Analysis of clonal relationship among Shigella sonnei isolates circulating in Argentina. Epidemiol Infect 135:681-687.

Sabra AH, Araj GJD, Kattar MM, Abi-Rached RY, Khairallah MT, Klena JD, Matar GM (2009) Molecular characterization of ESBL-producing Shigella sonnei isolates from patients with bacilliary dysentery in Lebanon. J Infect Dev Ctries 3:300-305.

Saran B, Erdem B, Tekeli FA, Sahin F, Aysev AD (2013) Characterization of Shigella strains isolated in Ankara, Turkey by antimicrobial resistance models, plasmid profile analysis and pulsed-field gel electrophoresis. Mikrobiyol Bul 47:3548.

Sidjabat HE, Paterson DL, Adams-Haduch JM, Ewan L, Pasculle AW, Muto CA, Tian G, Doi Y (2009) Molecular epidemiology of CTX-M-producing Escherichia coli isolates at a tertiary medical center in western Pennsylvania. Antimicrob Agents Chemother 53:4733-4739.

T.C. Saglik Bakanligi Temel Saglik Hizmetleri Genel Müdürlügü. 2006. Temel Saglik Hizmetleri Genel Müdürlügü Çalisma Yilligi 2005. Available at: http://www.saglik.gov.tr/istatistikler/temel2005/tablo-65.ht m. Accessed 4 June 2013.

Tenover FC, Arbeit RD, Goering RV (1997) How to select and interpret molecular strain typing methods for epidemiological studies of bacterial infections: A review for healthcare epidemiologists. Infect Control Hosp Epidemiol 18:426-439.

Varghese SR, Aggarwal A (2011) Extended spectrum beta-lactamase production in Shigella isolates- A matter of concern. Ind J Med Microbiol 29:76-78.

World Health Organization. 2005. Guidelines for the control of shigellosis, including epidemics due to Shigella dysenteriae type 1 Available at: http://whqlibdoc.who.int/publications/2005/9241592330.pdf. Accessed 4 June 2013.

Zafar A, Hasan R, Nizami SQ, Seidlein LV, Soofi S, Ahsan T, Chandio S, Habib A, Bhutto N, Siddiqui FJ, Rizvi A, Clemens JD, Bhutta ZA (2009) Frequency of isolation of various subtypes and antimicrobial resistance of Shigella from urban slums of Karachi, Pakistan. Int J Infect Dis 13:668-672.

All the content of the journal, except where otherwise noted, is licensed under a Creative Commons License CC BY-NC. 